\title{
Analysis of vitamin C enriched yoghurt by direct extraction of rosehip fruit in cow's milk during storage
}

\section{Ira Taneva ${ }^{1}$, Petar Panayotov ${ }^{2}$}

\author{
1 - Trakia University of Stara Zagora, Yambol, Bulgaria \\ 2 - University of Food Technologies, Plovdiv, Bulgaria
}

Keywords:

Milk

Yogurt

Rosehip

Vitamin C

Extraction

Article history:

Received

16.03.2019

Received in revised

form 14.05.2019

Accepted

28.06.2019

\section{Corresponding}

author:

Ira Taneva

E-mail:

ira_64@abv.bg

DOI:

$10.24263 / 2310-$

1008-2019-7-1-8

\section{Abstract}

Introduction. The aim of the present study is to obtain enriched in vitamin $\mathrm{C}$ yoghurt by direct extraction of rosehip fruit in cow's milk.

Materials and methods. Cow's milk from cows grown in the Yambol region was used to carry out extraction of rosehip fruits (R. Caniana). The content of vitamin $\mathrm{C}$ in the yoghurt obtained was determined by the Officials methods of analysis, 2000, as well as the total number of lactic acid microorganisms contained according to EN ISO 6610:2006; ISO 7889.

Results and discussion. The active acidity of the yoghurt was monitored during both periods of preparation and storage. At the end of the storage period (14 days), the active acidity reached $\mathrm{pH} 4,2-4,3$. For the same period, the vitamin $\mathrm{C}$ content was the highest in sample 2 and varied from $13,65-13,12 \mathrm{mg} \cdot \mathrm{g}^{-2}$.

The dry matter content in the yoghurt obtained was determined. Higher values of dry matter were observed in samples 2 and 3, with values varying from $12,60 \%$ to $13,4 \%$. The higher values of the dry matter content in the product were due to the pectin type substances extracted during the extraction process. The pectin substances extracted into the milk stabilized the coagulum, improved the taste and the nutritious value of the yoghurt obtained.

The total number of viable bacteria in the yoghurts obtained was determined and they were found to increase during the storage period. The highest total number of viable lactic acid bacteria was observed for Sample 2-3,6.10 CFU.g ${ }^{-2}$ which is about 10 times more than these in Sample 1 (reference).

Conclusions. The yoghurt obtained by direct extraction of dry rosehip fruits (Rosa canina L) into cow's milk at hydromodule 1:15 possessed the properties of functional food because of the content of vitamin $\mathrm{C}$ in it which varied from 13,65 to $13,12 \mathrm{mg} \cdot \mathrm{g}^{-2}$. The preparation of vitamin $\mathrm{C}$ enriched yoghurt can be used to produce new lactic acid products providing health benefits. 


\section{Introduction}

Yoghurt is highly popular fermented milk product on world scale due to its health benefits. It is obtained from cow's milk as a result of acidic coagulation of milk proteins induced by the lactic acid produced by Streptococcus thermophilus (S. thermophilus) and Lactobacillus delbrueckii subsp. bulgaricus [17].

It has been established that yoghurt has the same nutritious but higher biologic value compared to raw cow's milk. During the process of fermentation by its preparation, a number of biochemical changes occur which improve the absorption of lactose, lactic proteins and lactic acid by human organism [18].

The yoghurt consumption is high mainly in the Mediterranean countries, Asia and Central Europe. In some regions, yoghurt is produced as high viscosity liquid while on others - in the form of softer gel [8].

Since 2000, the development of new kinds of lactic acid products containing probiotics, prebiotics and components containing biologically active substances has substantially grown. Different methods for preparation of milk products enriched in biologically active substances have been implemented mainly by addition of fruits, vitamins, sweeteners, bee pollen, bee honey, etc., aiming to increase their biological value. [7, 9]. For the preparation of milk products enriched in biologically active substances, extracts of various fruits can be added $[4,24]$.

The manufacturing of extracts is usually connected with the process of extraction which leads to obtainment of one or several components from solid or liquid mixture by treatment with suitable solvent [21]. According to the solvent type, the extraction processes are classified as aqueous, alcoholic, hydroalcoholic, oil, etc., and according to the process itself - stationary and non-stationary.

No reports about methods related to direct extraction of fruits in raw milk, extraction of biologically active substances and manufacturing of enriched by them milk product (yoghurt) have been found in the literature.

Among plant species, the fruits of rosehip (R. canina) are characterized by high content of biologically active components, e.g. vitamins (C, B, P, PP, E, K), flavonoids, carotenes, carbohydrates (mono- and oligosaccharides), organic acids (tartaric and citric acid) microelements, etc. This is why the fruits are valuable raw material for the food and pharmaceutical industries and can be used for preparation of enriched extracts [12].

The aim of the present study is to develop a sample technology for production of vitamin $\mathrm{C}$ enriched yoghurt by direct extraction of dry rosehip fruits (R. canina) in raw cow's milk.

\section{Materials and methods}

\section{Materials}

For the manufacturing of vitamin $\mathrm{C}$ enriched yoghurt, cow's milk from cows grown in the region of Yambol was used, with $\mathrm{M}=3,6 \% ; \mathrm{pH}=6,6$; non-fat residue (NFO) $=8,7 \%$. The inoculant used was lyophilized starter culture (Lactobacillus delbreukii ssp bulgaricus, Streptococcus thermophilus), product of "Laktina" PLC, containing lactic acid bacteria more than $9,5 \times 10^{9}$ CFU.g ${ }^{-1}$.

The dry rosehip fruits (Rosa canina L.) used were grown in the region of Kyustendil, Bulgaria, harvested in 2016. Before the extraction, the fruits were washed, dried and ground to pieces sized 2,0-4,0 $\mathrm{mm}$. 


\section{Methods}

A method for preparation of vitamin $\mathrm{C}$ enriched yoghurt was developed and it is presented in Fig. 1. After quality control, acceptance, filtering and standardization of the milk by fats, stationary extraction of the raw milk with dry rosehip fruits was carried out. The extraction was performed at two hydromodules (dry rosehip fruits \& cow's milk) 1:15 and 1:20, temperature $0-4{ }^{\circ} \mathrm{C}$ and extraction duration 3 hours. At the end of the extraction period, the milk was filtered and pasteurized at temperature of $70-72{ }^{\circ} \mathrm{C}$ for $25 \mathrm{~min}$. the pasteurized milk was cooled to temperature $44-45{ }^{\circ} \mathrm{C}$ and inoculated with lyophilized starter culture (Lactobacillus delbreukii ssp bulgaricus, Streptococcus thermophilus). The amount of the inoculant was $4 \%$ vs the mass of the milk. The inoculated milk was kept at temperature $42-$ $45^{\circ} \mathrm{C}$ for 3-3,5 hours. After reaching $\mathrm{pH} 4,6-4,5$, the coagulated milk was homogenized (agitated), divided into portions and cooled to $18-20{ }^{\circ} \mathrm{C}$. The yoghurt obtained was further cooled and stored at temperature $0-4{ }^{\circ} \mathrm{C}$.

By the same technological scheme, a reference sample of yoghurt was prepared without extraction.

The samples of yoghurt obtained were analyzed at the moment they were obtained and then on $3^{\text {rd }}, 7^{\text {th }}$ and $14^{\text {th }}$ day of their storage. $[17,22]$.

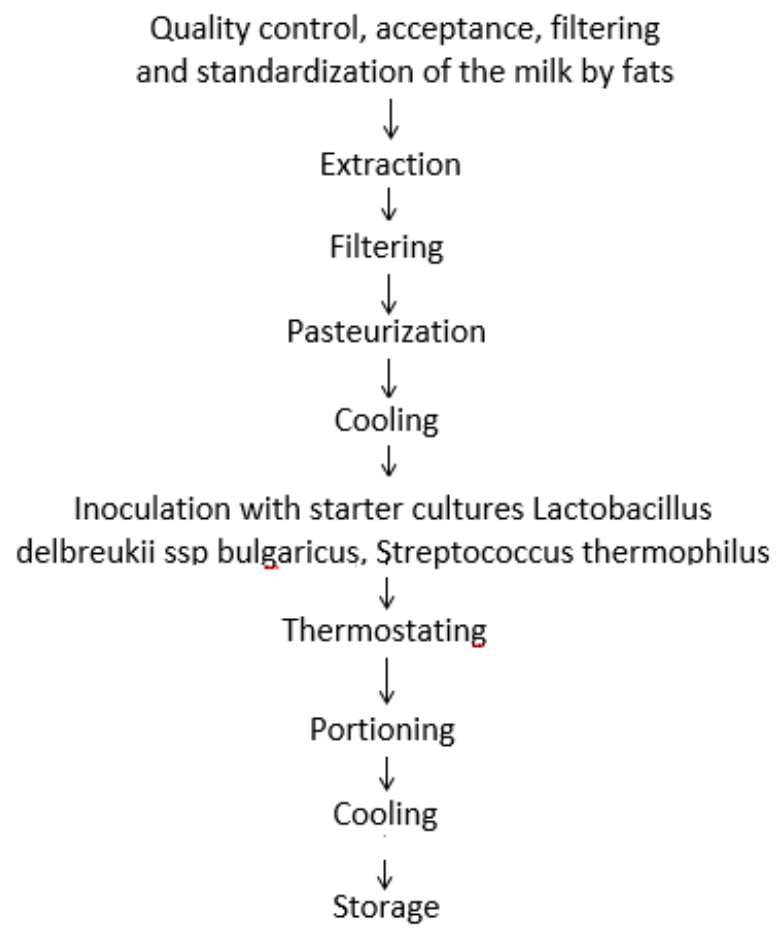

Figure 1. Sample scheme of the technological operations for production of yoghurt by extraction of rosehip fruits with cow's milk 


\section{Chemical methods of analysis}

Study of the dry rosehip fruits for their:

- Content of dry matter, $\%$ - [10];

- Titratable acidity, $\%$ - [1] ;

- Ascorbic acid, mg.10-2. $\mathrm{g}^{-1},-[13]$;

- Tanning matter, $\%$ - by exhausting extraction with hot water with reflux and titration of the extract obtained with $0,1 \mathrm{n} \mathrm{KMnO}_{4}$ and indicator indigo carmine,- [15];

Study of the yoghurt - yoghurt without extraction (Sample 1); yoghurt with extraction of rosehip fruits at hydromodule 1:15 (Sample 2); yoghurt with extraction of rosehip fruits at hydromodule 1:20 (Sample 3):

- Active acidity, pH - potentiometrically, by pH meter (Model MS 2011, Microsyst, Plovdiv, Bulgaria) equipped with electrode ( $\mathrm{pH}$ electrode Sensorex, Garden Grove, CA, USA);

- Dry matter, $\%$ - [5];

- Ascorbic acid, mg.10-2. $\mathrm{g}^{-1},-[13]$

- Number of lactic acid bacteria - [2];

\section{Sensory analysis}

The yoghurt obtained was estimated by specialists from the Faculty of Technics and Technology, Yambol, branch of the Trakia University of Stara Zagora, according to Badawi et al. [6] by the following properties: taste and flavor, superficies, color and residual taste.

\section{Statistical analysis}

The statistical analysis was carried out using OriginPro v.6.1 (OriginLab Corporation, USA), MS Excel and MS Word (Microsoft Corporation, USA).

Differences were considered to be significant at validity of $\alpha=0.95$.

\section{Results and discussion}

The chemical properties of the dry rosehip fruits used (Rosa canina L) are shown in Table 1. The rosehip fruits were estimated mainly by the contents of ascorbic acid (vitamin C), tanning substances and pectin. The fruits can accumulate up to $1000-4000 \mathrm{mg} \cdot \mathrm{g}^{-2}$ ascorbic acid and 4,5-6,8\% tanning substances $[3,14,16]$. The chemical composition of the fruits analyzed was comparable with the literary data and the contents of the other components in other representatives of the same family.

\section{Chemical properties of rosehip fruits}

Table 1

\begin{tabular}{|c|c|c|c|}
\hline $\begin{array}{c}\text { Dry } \\
\text { matter,\% }\end{array}$ & $\begin{array}{c}\text { Titratable } \\
\text { Acidity,\% }\end{array}$ & $\begin{array}{c}\text { Ascorbic acid, } \\
\text { mg.g }^{-2}\end{array}$ & Tanning substances, \% \\
\hline $88,7 \pm 0,08$ & $2,4 \pm 0,09$ & $2640,9 \pm 0,06$ & $5,5 \pm 0,05$ \\
\hline
\end{tabular}


The high content of ascorbic acid (vitamin C) found in the rosehip fruits has values (2640,9 mg. $\mathrm{g}^{-2}$ ) which allow using them as additive for preparation of vitamin $\mathrm{C}$ enriched yoghurt.

The active acidity of the yoghurt obtained (Samples 1, 2 and 3) was measured immediately after its preparation and during the storage period - on $3^{\text {rd }}, 7^{\text {th }}$ and $14^{\text {th }}$ day (Fig.2). the values of the active acidity of the yoghurt decreased during the storage, as shown in Fig.2.

The lower values of the active acidity for Sample 2 on the $10^{\text {th }}$ day $(\mathrm{pH} 4,2)$ of the storage period was most probably due to the biologically active substances and organic acids extracted from the fruits during the extraction.

The organic acids and pectin introduced during the extraction did not affect the coagulation process because it has been proved that the stabilization of casein is effective in the $\mathrm{pH}$ interval 3,2-4,7 [11,23].

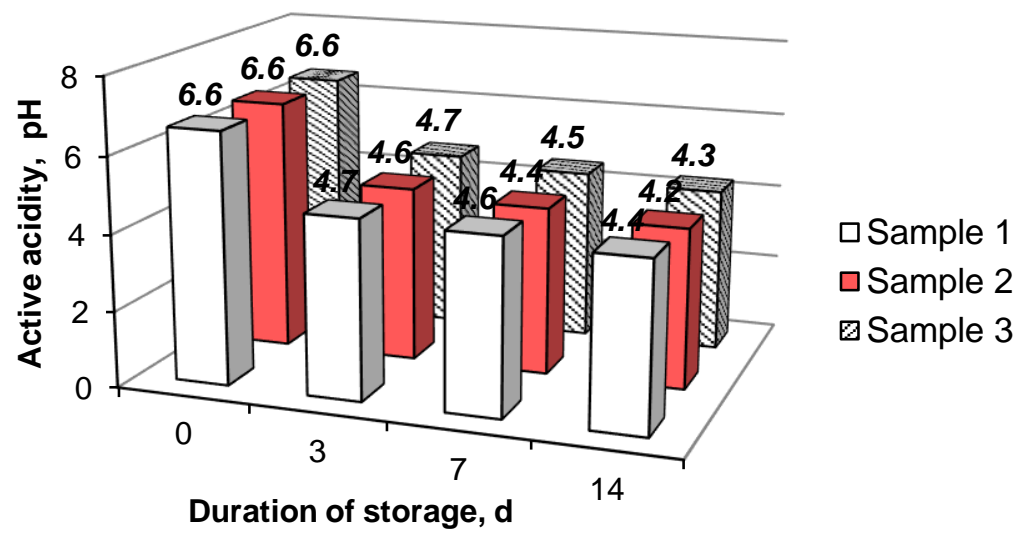

Figure 2. Effect of the storage duration on the active acidity of the yoghurt obtained

Table 3 shows the values of dry matter content in the yoghurt obtained. The dry matter had higher values for samples 2 and 3 and varied from $12,60 \%$ to $13,4 \%$. The higher values of dry matter content in the yoghurt were due to the pectin substances extracted during the extraction process. The pectin contained in rosehip fruits varies from 5 to $10 \%$ of the absolute dry matter of the fruit [3]. The pectin substances in the milk improve the nutritious value of the yoghurt.

Dry matter contents in vitamin $C$ enriched yoghurt

Table 3

\begin{tabular}{|c|c|c|c|}
\hline \multirow{2}{*}{$\begin{array}{c}\text { Duration } \\
\text { of storage, day }\end{array}$} & Dample 1 & Sample 2 & Sample 3 \\
\cline { 2 - 4 } & 12,1 & 12,6 & 13,4 \\
\hline Fresh & 12,2 & 12,7 & 13,4 \\
\hline 3 & 12,2 & 12,7 & 13,4 \\
\hline 7 & 12,2 & 12,7 & 13,4 \\
\hline 14 &
\end{tabular}


The content of vitamin $\mathrm{C}$ (ascorbic acid) in the yoghurt obtained was studied. It is well known that the dry rosehip fruit tissue contains $2200 \mathrm{mg} . \mathrm{g}^{-2}$ ascorbic acid which makes it 3040 richer in this vitamin compared to red tomatoes and 300 times richer compared to apples [19].

It is obvious from the results presented in Table 3 that the content of ascorbic acid extracted during the extraction was the highest in Sample $2-13,65 \mathrm{mg} \cdot \mathrm{g}^{-2}$ and remained almost the same until the $14^{\text {th }}$ day of storage of the yoghurt.

For the same period, the values of vitamin C content in Sample 3 were 11,45-11,30 $\mathrm{mg} . \mathrm{g}^{-2}$. The higher vitamin C content in Sample 2 was due to the lower hydromodule used in the extraction process.

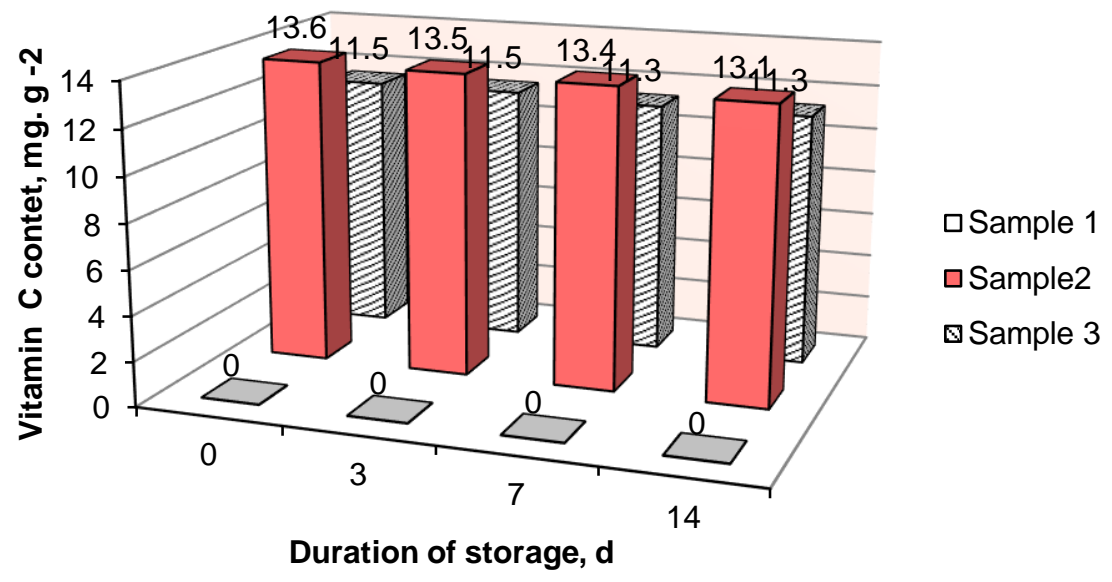

Figure 3. Effect of storage duration on the vitamin $\mathrm{C}$ content in yoghurt

The total number of lactic acid bacteria in the yoghurt obtained was studied. The data presented in Table 4 showed that the total number of Str. thermophilus, L. delbrueckii ssp.bulgaricus had not been affected by the extraction of biologically active substances during the extraction process.

The total number of viable bacteria gradually increased until the end of the storage period. Higher number of bacteria was observed in Sample 2 compared to the reference (Sample 1) at the end of the storage. Similar results were obtained by Stijeptic [20] who found that the yoghurt enriched in combination of whey protein concentrate and $4 \%$ honey had the highest content of lactic acid during the storage period.

As a result of the studies discussed above, the samples of yoghurt obtained comply with the requirement of Codex alimentarius for the content of probiotic microorganisms in inoculated milk products which should contain at least $10^{7}$ viable cells.

The organoleptic properties of the yoghurts obtained were determined with respect to their color, taste and fragrance, superficies, residual taste and consistence. 
Table 4

Number of lactic acid bacteria in yoghurt during the storage period

\begin{tabular}{|c|c|c|c|c|c|c|c|}
\hline \multirow{2}{*}{ No. } & \multirow{2}{*}{$\begin{array}{c}\text { Duration of } \\
\text { storage, }\end{array}$} & \multicolumn{3}{|c|}{$\begin{array}{c}\text { CFU g product } \\
\text { Sample 1 }\end{array}$} & \multicolumn{3}{|c|}{$\begin{array}{c}\text { CFU g product } \\
\text { Sample 2 }\end{array}$} \\
\cline { 2 - 8 } & Lactobacilli & $\begin{array}{c}\text { Strepto } \\
\text { cocci }\end{array}$ & Total & Lactobacilli & $\begin{array}{c}\text { Strepto } \\
\text { cocci }\end{array}$ & Total \\
\hline 1. & Fresh & $1,2.10^{7}$ & $4,610^{7}$ & $5,8.10^{7}$ & $1,2.10^{7}$ & $4,6.10^{7}$ & $5,8.10^{7}$ \\
\hline 2. & 3 & $2,3.10^{8}$ & $2,1.10^{9}$ & $2,3.10^{9}$ & $2,4.10^{8}$ & $2,8.10^{9}$ & $3,04.10^{9}$ \\
\hline 3. & 7 & $1,1.10^{8}$ & $1,0.10^{9}$ & $1,1.10^{9}$ & $1,2.10^{8}$ & $1,3.10^{9}$ & $1,4.10^{9}$ \\
\hline 4. & 14 & $2,6.10^{6}$ & $3,2.10^{8}$ & $3,5.10^{7}$ & $2,5.10^{7}$ & $3,4.10^{8}$ & $3,6.10^{8}$ \\
\hline
\end{tabular}

Table 4 (continue)

\begin{tabular}{|c|c|c|c|c|}
\hline \multirow{2}{*}{ No. } & \multirow{2}{*}{ Duration of storage,d } & \multicolumn{3}{|c|}{ CFU g product } \\
\cline { 3 - 5 } & & Lample 3 \\
\cline { 3 - 5 } & & Lactobacilli & $\begin{array}{c}\text { Strepto } \\
\text { cocci }\end{array}$ & Total \\
\hline 1. & Fresh & $1,2.10^{7}$ & $4,610^{7}$ & $5,8.10^{7}$ \\
\hline 2. & 3 & $2,1.10^{8}$ & $2,6.10^{9}$ & $2,8.10^{9}$ \\
\hline 3. & 7 & $1,1.10^{8}$ & $1,4.10^{9}$ & $1,5.10^{9}$ \\
\hline 4. & 14 & $2,3.10^{7}$ & $3,1.10^{8}$ & $3,3.10^{8}$ \\
\hline
\end{tabular}

The yoghurt Sample 2 obtained was given higher values for taste and flagrance, superficies and consistence compared to Samples 1 and 2 (Fig.4). The yoghurt Sample 2 had thicker consistence and more pronounced taste and flagrance. For Sample 2, residual taste of rosehip was perceived as a result of the extraction carried out but it didn't worsen the yoghurt taste.

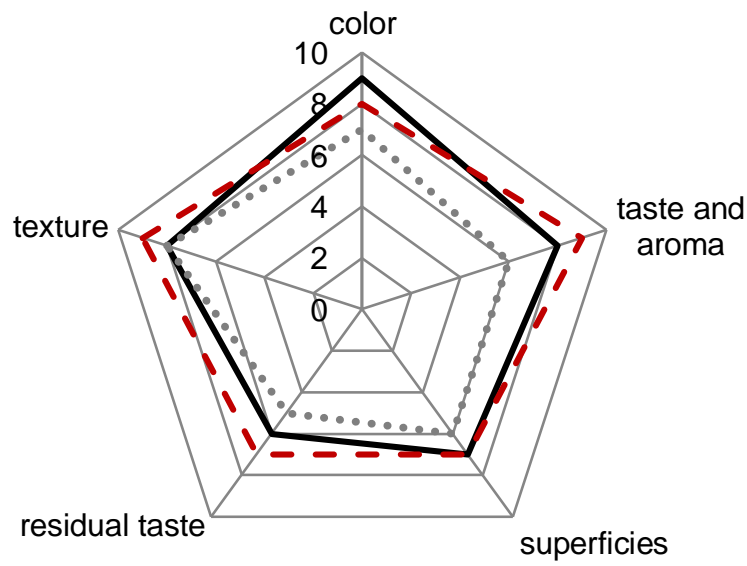

Sample 1

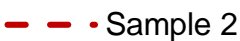

-..... Sample 3

Figure 4. Organoleptic estimation and sensor profile 


\section{Conclusion}

The yoghurt obtained has properties of a functional food resulting from the direct stationary extraction of dry rosehip fruits (Rosa canina $\mathrm{L})$ in cow's milk at two hydromodules $1: 15$ and $1: 20$.

The active acidity of the yoghurt was established in both periods of preparation and storage. At the end of the storage period ( $14^{\text {th }}$ day), the active acidity reached $\mathrm{pH} 4,2-4,3$. For the same period, the content of vitamin $C$ was the highest in Sample 2 and varied from 13,65$13,12 \mathrm{mg} \cdot \mathrm{g}^{-2}$.

The total number of viable bacteria in the yoghurts obtained was determined and the values of this indicator were found to gradually increase during the storage period; for Sample 2 it was $3,6.10^{8}$ CFU.g ${ }^{-2}$ which is 10 times higher than that of Sample 1 (reference). It makes the yoghurt obtained an useful and healthy dairy product.

The direct extraction of dry rosehip fruits in raw cow's milk improves the organoleptic properties of the yoghurts obtained.

The preparation of vitamin $\mathrm{C}$ enriched yoghurt by direct extraction of fruits can be used for manufacturing new lactic acid products with health benefits.

\section{References}

1. AOAC Association of Official Analytical Chemists (2000), Acidity/Titratable Acidity

2. BNS ISO 7889 Lactobacillus delbrueckii subsp. Bulgaricus, ISO 7889 Streptococcus thermophilus

3. Zimin E. (2001), Collection variety study of multivitamin and large-fruited rosehip in the Khabarovsk Territory, Materials of the international seminar "Forest biologically active resources, Khabarovsk, pp. 313-319.

4. Mustafina A.S., (1999) Development of technology of fruit extracts for the purpose of their use in the production of dairy products: Author's abstract. dis. Cand. tech. sciences. Kemerovo.

5. A.O.A.C. Association of Official Analytical Chemists (2000), Official Methods of Analysis of Association of Official Agriculture Chemists. Wiscosin. George Banta Co. Inc.

6. Badawi, R., Hamed, A., Kebary K. and El- Sayed, H. (2008), Effect of replacing milk fat with fat replacers on the quality of stirred yoghurt, Egyptian J. Dairy Sci., 36, pp. 197-206.

7. Bills D., Yang C.S., Morgan M. and Bodyfelt F. (1972) Effect of sucrose on the production of acetaldehyde and acids by yogurt culture bacteria, Journal of Dairy Science, 55, pp. 1570-1573

8. Caballero, B., Finglas, P., and Toldrá, F. (2016), Yogurt: The Product and its Manufacture, The Encyclopedia of Food and Health, 5, pp. 617-624.

9. Chen L., Mehta A., Berenbaum M., Zangerl A. and Engeseth N. (2000), Honeys from different floral sources as inhibitors of enzymatic browning in fruit and vegetable homogenates, Journal of Agricultural and Food Chemistry, 48, pp. 4997-5000 .

10. ISO 1026:1982. Fruit and vegetable products -- Determination of dry matter content by drying under reduced pressure and of water content by azeotropic distillation, Available at: https://www.iso.org/standard/5498.html

11. Laurent M., Boulenguer P. (2003), Stabilization mechanism of acid dairy drinks (ADD) induced by pectin, Food Hydrocolloids, 17, pp. 445-454, 
12. Mabellini M., .E.Ohaco., M. Ochoa, A. Kesseler, C. Márquez, A.De Michelis A., (2011), Chemical and Physical Characteristics of Several Wild Rose Species Used as Food or Food Ingredient, International Journal of Industrial Chemistry, 2( 3), pp. 158171.

13. (2000), Officials methods of analysis (14th ed.) Association of Official Analytical Chemist, Arlington, VA, USA, 2000.

14. Orhan N., M. Aslan, S. Hosbas, O. Deliorman (2009), Antidiabetic effect and antioxidant potential of Rosa canina fruits, Pharmacognosy Magazine, 5(20), pp. $309-$ 315.

15. Patel AV, Patel KN, Patel MS. Validated simple redoxtitration method for the estimation of gallotannins in marketed ayurvedic churna preparations. (2011), Journal of Chemical and Pharmaceutical Research, 3, pp. 293-299.

16. Rahnavard A., A. Ghavamaldin, T. Ahmad, T. Mariamalsadat (2013), Evaluation of biochemical compounds Rosa cannia L. in North of Iran Ramsar and Tonekabon Heights, Journal of Medicinal Plants Research,7 (45), pp. 3319-3324.

17. Robinson, R.K., (2003), Yoghurt types and manufacture. In: Roginski, H.,Fuquay, J.W., Fox, P.F. (Eds), Encyclopedia of Dairy Sciences, vol. 2. Academic Press and Elsevier Science, Amsterdam, Boston, London, New York, Oxford, Paris, San Diego, San Francisco, Singapore, Sydney, Tokyo., pp. 1055-1058.

18. Savadogo A., C.A.T. Ouattara, I.H.N. Bassole and S.A. Traore. (2006), Bacteriocins and lactic acid bacteria - a minireview, African Journa Biotechnol, 5, pp. 678--683.

19. Soner K., H. Baydar, S. Erb (2009), Variations in chemical compositions of Rosa damascene Mill. and Rosa canina L. fruits, Czech Journal of Food Sciences, 27(3),pp. $178-184$.

20. Stijeptic, M., D.Durdevic, J.Jovanaglusac, (2012), Production of low fat yoghurt enriched with different functional ingredients, Quality of Life (Banja Luka), 3(1-2), pp. 5-12.

21. Sukhdev H., S.Preet, S.Khanuja, G. Longo, D. Rakesh. (2008), Extraction Technologies for Medicinal and Aromatic Plants, International Centre for Science and High Technology, Italy.

22. Tamime and Robinson, (1999), Yoghurt science and technology (2 nd ed.), Cambridge. Woodhead Publishing Ltd.

23. Tanhatan N., François T., M. Ralet. (2008), Citrus pectin: structure and application in acid dairy drinks, Tree and Forestry Science and Biotechnology, 2(1), pp. 60-70.

24. Zlatev, Z., Petev M., Dimitrova A., Simeonova V., Dinev S., Dineva J. (2015), Analysis of methods and tools for evaluation the quality of yogurt, Journal of Innovation and entrepreneurship, III, pp.41-57. 